\title{
Impunity's psychological effects: its ethical consequences
}

\author{
Diana R Kordon Buenos Aires, Argentina
}

During the last military dictatorship in Argentina (1976-83) a most fierce political repression developed which led to one of the blackest periods of the history of our nation and left thousands of dead, disappeared and exiled.

Physical and psychiatric torture was systematically implemented and applied on every prisoner. As a consequence of this repression, characterised as terrorism of the state, a new legal category appeared: the disappeared-detainee.

We have already discussed, in other papers, how the political repression and the forced disappearance of people affects the community as a whole, the victims themselves, and their families, in a psychological and sociological sense. It is our aim now to deal with the psychological and sociological effects as well as the ethical implications of impunity, particularly in our professional field.

During the time of the dictatorship several psychological-inducement campaigns were developed based on three elements:

a) a regime of terror,

b) an absolute monopoly and control of the mass media by government,

c) statements with an identification message.

The three elements together formed an attempt to capture vast community sectors which had to accept the message under risk of death. The campaigns' aim was to keep the population inactive politically by means of terror and/or confusion. The community was thus largely reduced to social silence, to blaming the victims, and believing their own responsibility in these matters was minimal.

Various social representations were encouraged by the dictatorship during the course of time. All of these basically aimed to hide the political repression that was taking place and to make people think in terms of a scene that can be summarised as follows: the country was being attacked by a foreign enemy which had such an ability to blend with the local population that its army became invisible. Needless to say, most people did not believe this representation.

A very peculiar psychological inducement campaign was devised in order to psychiatrise the opposition parties and, especially, the Mothers of Plaza de Mayo and any political activity that might mean resistance. Thus, the Mothers of Plaza de Mayo became 'those old lunatics' or 'las locas de Plaza de Mayo', as many of the dictatorship officials would call them. Every political struggle or attempt to change was immediately discouraged and qualified as senseless or sterile, the message being: nothing can be done against us, we monopolise the force and the power, give up your fight and accept it.

With the coming of the democratic government of Alfonsín, (December 1983-July 1989) an outstanding popular movement demanded punishment for the guilty and, headed by the Mothers of Plaza de Mayo demanded that a parliamentary investigating commission be created which would have full power to enter and investigate military barracks and which would have access to security forces' intelligence archives, etc. Instead, a series of proceedings took place which at first masked what would end with the passing of two Acts, known as the Full Stop Law and the Due Obedience Law, which exempted thousands of repressors and torturers from any legal responsibility and left them free.

Silence was no longer possible and living in a democracy, we were able to speak. There then appeared what some media called 'The Horror Show'. This consisted of a pseudo-hyperinformation exercise on the most macabre and withstanding aspects of repression: Tombs, exhumations, human remains, description of torments - all were splashed onto the audience by government agencies in order to produce an emotional impact or, at best, a catharsis. Everything was contextless, avoiding the whys and wherefores. The apparent overinformation was aimed at causing a saturation that counteracted any possible discussion of the subject in order to make the people think of something else. Again, silence on the subject prevailed. What in previous times had been an attempt to psychiatrise was now an attempt to psychologise. The Mothers of Plaza de Mayo were no longer the dictatorship's 'lunatics', but rather those actually in power would say: 'We respect your grief but do not share your claim: it is simply impossible to give it credence'. (Their claim was: 'We want our lost ones back alive; we want trial and punishment for the 
guilty'.) Or, those in power would say: 'We understand you but you are destabilising democracy'.

Now the aim was to invalidate the Mothers' or others' political opposition by pretending an emotional commitment to their theme. The campaign in favour of dilution of responsibility goes on today and expressions such as: 'All of us were responsible', or 'We all make mistakes', are still heard.

By application of the Due Obedience Law, no individual responsibility exists for those who committed crimes (such as kidnappings, torture, homicides) in due obedience to an order received from their superior in rank, but it is alleged that it is the latter, the one who gave the order, who is to be incriminated (later, we shall see that not even these are punished, as they are benefited by a decree of amnesty; therefore, the question now arising is: 'Is the victim/ object of the crime perhaps the one responsible?'). And here we come full circle: once more, it is the victim who is guilty because the person who executed the criminal action, kidnapping or torturing people, was either unable to discern what he was doing on account of his lower rank, or he was unable to rebel because of the prevailing process of coercion. According to this law, the captain executing an order from the colonel above him would be unable to ascertain he was actually torturing just because of his lower rank. The idea that a lower degree is coupled with less discernment seemed to be a consequence of Darwin's theory. The climate of coercion endorses the notion of war proposed by the dictatorship. On another level of analysis, the Due Obedience Law says that crimes such as kidnapping, torture and homicide, are not crimes if committed in compliance with a military order, or, if they are, there are no offenders. Please note, how inducement to dilution of responsibility persists. The previous: 'We are all responsible', now becomes 'nobody is responsible'. Again, by conversion, the effect of the discourse is the same.

In July 1989, President Menem took office. The social and economic circumstances in which this change of government took place must be pointed out. President Menem took office three months before Alfonsín's term ended amidst the most serious economic crisis and the absolute discredit of the government in power.

President Menem, though himself a victim of the dictatorship (he was in prison for five years), took the decision to release the few found guilty of genocide who were still in prison, using the political and legal measure of a decree of amnesty or pardon. The first part of this has already been implemented.

The President further declared that during the course of 1990 he would bestow a presidential pardon on the six remaining genocide-convicted prisoners. Indeed, on December 30th 1990, these six were released.

It must be pointed out that although the power to pardon is a constitutional power vested in the president, which constitutes an act of grace exclusive and independent of social consensus, it was preceded by several multitudinous opposition rallies against the presidential pardon.

According to most reliable surveys, over 63 per cent of the population is against the granting of such a pardon. Such a pardon constitutes an anti-legislation act since it lacks all social consensus and creates a system of privileges and exceptions questioning accepted ethical and legal norms and values.

The dictatorship's inducement to silence and the following 'Horror Show' are presently continued by a fascicular approach to history. According to this idea, history appears in fascicles or chapters, one chapter closing before another one opens. Such an atomised vision of history denies the permanent review that a society is constantly making of the significance of its past and certain historical events. Making use of this view of history the government asks us to see the impunity which has been granted to those who have committed genocide as concluding 'one of the chapters of our history'.

Therefore, justice, according to our present legislation, operates on three levels:

a) As a symbolic reparation. It partly repairs, as is in the very nature of a reparation, but can never bring things back to the status they had prior to the criminal action since damage has already occurred; it admits the existence of damage, of a person injured and of an offender. The conviction proportionate to the crime operates as a social redress and justice constitutes not only a social value but a function: the function of justice being a way of controlling impulses in relation to the offender.

b) As a social norm. It operates to regulate social exchanges and relationships which it actually protects since it establishes what can and cannot be done. Deletion of this level would lead the individual to a situation of anomie where he would find himself defenceless and with a sense of helplessness, not knowing what to do, where everything is admitted, where there is no discrimination as a result of the breakdown of standards and values.

c) Finally, the law operates as a cohesive social element since its universal value ensures the union of all members of society (remember the cohesive effect of incest law). Deletion of this level in any form would bring about social disintegration.

We strongly believe that the pardon granted to those guilty of genocide will affect the three operational levels mentioned above since it is justice and not oblivion that maintains social peace and unity.

We similarly believe that the psychological and social effects of impunity should be considered on two levels: the immediate and the long term. It is with these two levels in mind that we are developing our clinical research and our assistance to those directly involved.

The policy of impunity has spread, on a mass scale, the tendency to blame the victim. This is also valid for 
social situations of a more general character which are not directly determined by human rights violations. Impunity makes it possible for a man such as General Bussi, former governor of Tucumán (an Argentinian province where political persecution was extremely cruel) who was in charge of dozens of concentration camps, to be presently running as governmental candidate for the same province.

The never-ending issue of restoring kidnapped children to their legitimate, natural families has engendered a discussion on the adoption procedure in force in Argentina. Every adoption that took place during the dictatorship should be minutely reexamined. Certainly, every couple who adopted a child during those years should be doubtful as to the real origin of the adopted child. Could he or she be a child of a missing person? This question is qualitatively different from the doubt any adopting parent may feel regarding the origin of an adopted child when the adoption has taken place under normal circumstances.

Within our own professional field of psychiatry, impunity and economic crisis also present a series of questions on the fundamental aspects of our practice. Thus, once the decree of amnesty had been passed, the mother of one of the missing said: 'When I take the subway I always think that the person who is sitting next to me may be my son's assassin'. Is this paranoia or realism? We are saying that impunity exempts all those who participated in torture or other human rights violations of the sanction imposed by the state.

Amongst health professionals it has been agreed not to give psychotherapeutic treatment to torturers who have not paid the penalty provided for such crimes. Often, professionals in state hospitals have denied assistance to former repressors, alleging that it was first necessary that they settle accounts and pay their debt to society. With the introduction of the Full Stop Law and the Due Obedience Law torturers have been exempted from this debt. Now, it is the professionals, who, having denied their psychiatric assistance to such people, are being subjected to sanction by the state or the professional institution to which they belong.

Another aspect that particularly affects the professional sector of psychiatry and medicine is that doctors and other health providers who have participated in torture and children kidnapping are still practising. These people too are exempted from legal sanctions.

In our country, most of our professional organisations have not implemented ethical sanctions against such professionals.

Furthermore, ethical codes have not been amended to cover those cases which have occurred so often within the last 15 years.

The proposal to adopt sanctions for those colleagues who have participated in any form of political repression has been promoted by us, the professionals who are actually assisting the victims of the political repression. Therefore we have, amongst other things, held an ethical tribunal of health providers against impunity. This tribunal was held in the Aula Magna of the Buenos Aires University, the Faculty of Medicine, on December 3, 1987. More than two thousand health professionals participated in this tribunal where ethical sanctions were proposed against those professionals charged with:

1. Violation of the Hippocratic oath.

2. Violation of the National Code of Ethics and $\mathscr{\infty}$ international legislation governing the medical $\overrightarrow{0}$ profession.

3. Co-participation in:

a) Tortures.

b) Forced disappearence of children.

c) Forging of documents so that kidnapped $\vec{V}$ children, or those who were born in prison and is taken away from their parents, could be falsely registered by the adoptive parents as their own son or daughter.

The number of children born in captivity under the dictatorship amounts to 131 and there are 450 kidnapped children, of whom only 50 have been restored to their original families.

Our tribunal, or jury, was presided over by the $\underset{\mathbb{\Phi}}{\overparen{D}}$ Attorney-General and it was attended by many representatives from the medical, cultural, artistio $\&$ religious and labour fields as well as from human righs. organisations.

The tribunal demonstrated, with the participation of witnesses, that doctors Jorge Antonio Bergez, Héctor Jorge Vidal and Julio Ricardo Estévez, had taken part in torture and had therefore committed crimes against the Argentinian people and citizens from other $\overrightarrow{\vec{\sigma}}$ countries as well. Symbolically, through these three 3 doctors, we have judged all the professionals - doctors, midwives, psychologists, odontologists, nurses, etc who participated in one way or another in crimes against the people after the military coup in 1976.

The list of the accused doctors includes the names of ten medical professionals who were tried, and in some cases condemned to prison, and later liberated, thanks to the Due Obedience Law.

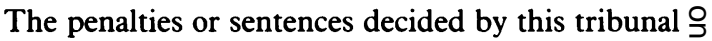
did not refer to confinement in prison, but were the $\rightarrow$ expression of a social rejection of the crimes committed and their authors and urged the professional N community to expel them from their organisations, from the academic community, and from society as a whole.

At the same time the tribunal demanded punishment from the state for those found guilty of 0 repression during the dictatorship. The tribunal's $\stackrel{2}{\mathbb{D}}$ decision was a confirmation of the American poet, $\stackrel{\infty}{+}$ Mario Benedetti's, words:

'... the only remedy for injustice is not just not to forget, but that justice be done ...'.

In defence of the medical profession, and of all health 
professionals, let us make every effort so that no doctor who has been participating in crimes against the people can ever be permitted to practise professionally, either in his/her own country or in any other place in the world.

I want to finish by quoting an expression from the president of our tribunal, in which he reaffirms the historical necessity for holding such ethical trials:
'Let us firmly keep up the principles of Law, Liberty and Dignity and face properly the responsibilities life may place before us because life without LIBERTY, without DIGNITY and without JUSTICE is not worth living.'

Diana $R$ Kordon, $M D$, is a psychiatrist and a member of the Plaza de Mayo Group in Buenos Aires, Argentina. 